\title{
Tidal Current Energy Resources Assessment in the Patinti Strait, Indonesia
}

\author{
Franto Novico a*, Evi Hadrijantie Sudjono ${ }^{a}$, Andi Egon ${ }^{b}$, David Menierc, \\ Manoj Methew d, Munawir Bintang Pratama ${ }^{\mathrm{e}}$ \\ a Marine Geological Research and Development Center, Ministry of Energy and Mineral Resources, Indonesia \\ ${ }^{b}$ Department of Oceanography, Bandung Institute of Technology, Indonesia \\ c Géosciences Océan UMR CNRS 6538, Université Bretagne Sud, 56017 Vannes Cedex, France \\ d South-East Asia Carbonate Research Laboratory, Universiti Teknologi PETRONAS, Perak, Malaysia \\ eDepartment of Coastal Engineering, Bandung Institute of Technology, Indonesia
}

\begin{abstract}
Indonesia is currently intensively developing its renewable energy resource and targets at least $23 \%$ by 2025 . As an archipelago country, Indonesia has the potential to benefit from its abundant renewable energy resources from its offshore regions. However, the short tidal range of mixed semi-diurnal and the suitable tidal turbine capacity may hinder marine renewable energy development in Indonesian waters. This paper presents higher-order hydrodynamic numerical models to provide spatial information for tidal current resource assessment of the Patinti Strait. The present study applied the hydrographic and oceanographic method to produce input of the numerical model. Based on the selected simulation analysis, the highest current speed could be identified around Sabatang and Saleh Kecil Island with up to $2.5 \mathrm{~m} / \mathrm{s}$ in P1 and $1.7 \mathrm{~m} / \mathrm{s}$ in P4. Besides, the operational hours for the two observation points are $69 \%$ and $74.5 \%$, respectively. The results indicate that this location is of prime interest for tidal turbine implementation as an energy source, for medium capacity $(300 \mathrm{~kW})$ and high capacity $(1 \mathrm{MW})$.
\end{abstract}

Keywords: Tidal current, renewable energy, resource assessment, numerical model, Indonesia

Article History: Received: 14 $4^{\text {th }}$ Dec 2020; Revised: $15^{\text {th }}$ Feb 2021; Accepted: 24 $4^{\text {th }}$ February 2021; Available online: $1^{\text {st }}$ March 2021

How to Cite This Article: Novico, F., Sudjono, E. H., Egon, A., Menier, D., Methew, M., Pratama, M. B., (2021) Tidal Current Energy Resources Assessment in the Patinti Strait Indonesia. International Journal of Renewable Energy Development, 10(3), 517-525

https://doi.org/10.14710/ijred.2021.35003

\section{Introduction}

Global warming has been alarming in the past years, as the earth temperature increases by $0.08^{\circ} \mathrm{C}$ per decade (NOAA, 2020). This evidence is backed by a study demonstrating that atmospheric $\mathrm{CO}_{2}$ reached over 400 ppm in 2018 and went over the natural state, which was between 170 to 300 ppm (Ritchie \& Roser, 2017). A number of local, regional or even global efforts are initiated, aiming to slow down the temperature rise, and the most addressed issue is arguably the plan for reducing dependency on fossil fuel. Currently, oil, gas and coal account for more than $80 \%$ of primary energy consumption (BP, 2019). The utilisation of low-carbon energy is expected to meet the energy demand while substituting these conventional energy sources.

At present, Indonesia relies heavily on conventional energy resources such as oil, gas and coal. In densely populated islands, such as Java and Sumatra, the operational cost for oil, gas, or coal energy is at an economically feasible level (Ministry of Energy and Mineral Resources of the Republic of Indonesia, 2018).
However, this does not apply to small, remote and less populated islands where the operational cost can be significantly higher because of expensive logistics. Moreover, these unsustainable energy resources are limited and will have to be supplemented by a renewable source of energy in the future.

The 23\% renewable energy target in 2025 has become an urgent issue for Indonesia (PLN, 2017). Marine energy is listed as one of the renewables, which the technology classified into the tidal barrage, tidal current, waves, ocean thermal energy, and salinity gradients (OES, 2019). Tidal barrage offers a mature technology such as the one demonstrated in La Rance, France. However, it requires a massive coastal dam to create a head differential. Furthermore, Indonesia's tidal range is not too high to produce a consistent current speed required to drive the turbine. Among the other technologies, tidal current is more preferred because of its predictability and technology advancement. This paper then discusses the condition of tidal current in the Patinti Strait concerning the type of turbine to be used.

\footnotetext{
* Corresponding author: franto.novico@esdm.go.id
} 

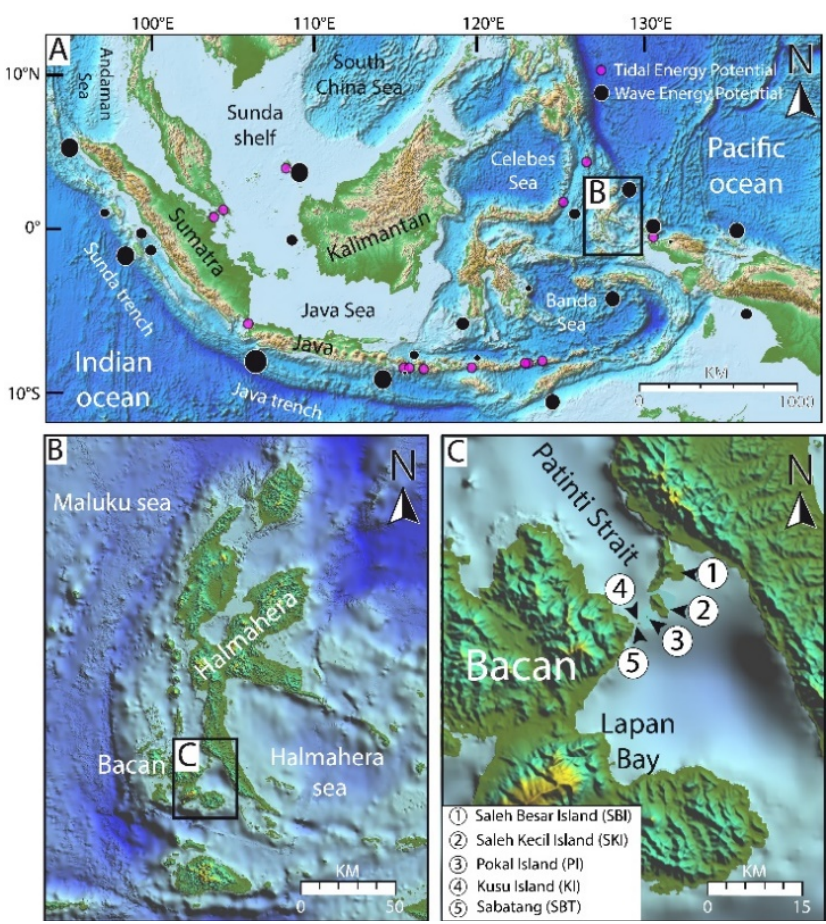

Fig. 1 (A) The regional and (B-C) local study area. (Source: https://earthexplorer.usgs.gov/)

As an archipelago country, Indonesia is suitable for the exploitation of a marine renewable energy source, as the potential tidal current and ocean wave energy is enormous (Fig. 1A). Currently, three straits have been studied extensively for tidal current energy development, namely Lombok, Alas and Larantuka Straits, located in Bali, Nusa Tenggara region (Blunden et al., 2013; Orhan et al., 2015; Firdaus et al., 2019; Firdaus et al., 2020; Orhan \& Mayerle, 2020). Besides, researchers have also demonstrated potential in other sites such as Kelabat Bay, Sunda, Boleng, Molo, and Pantar Straits (De Groot, 2012; Sudjono et al., 2014; Novico et al., 2015; Ajiwibowo et al., 2017; Pratama et al., 2020). Furthermore, summaries on multiple tidal current energy sites are provided in several previous studies (Susilohadi et al., 2014; Kementerian ESDM, 2017). Even though Indonesia has enormous ocean and many narrow straits, the number of prior studies related to the possible implementation of marine renewable energy in Indonesia is still limited.

North Maluku Province is one of the national targets for research related to marine renewable energy. It is one of the national fish barns that still have a deficit of energy in their remote area. Furthermore, Rahmawati (2017) revealed that several offshores in North Maluku have potency for tidal current energy. Thus, the study on tidal currents has been completed in this province, particularly in Patinti Strait. The Patinti Strait is one of selected locations for research by the Indonesia Ministry of Energy and Mineral Resources. This activity is part of updating the ocean current energy potential maps of Indonesia.

The Patinti Strait (PS) is located between Bacan Island (BI) and Halmahera Island (Fig. 1B). The smallest width of the PS is approximately $16.33 \mathrm{~km}$, with several islands in this region. The Saleh Besar Island (SBI) is the largest island; the others are Saleh Kecil Island (SKI), Kusu Island (KI) and Pokal Island (PI) (Fig. 1C). The strait depths vary, ranging from depths of $10 \mathrm{~m}$ to $500 \mathrm{~m}$ in the northern part of SBI and $20 \mathrm{~m}$ to more than $1500 \mathrm{~m}$ in the southern part (Pushidros TNI AL, 2011). The depth near $\mathrm{KI}$ and PI is less than $200 \mathrm{~m}$. Local inhabitants stated that the life risk for people under taking maritime activities like vessel traffic in this area is very high because of its unpredicted high currents and waves. They called this region Tanjung Neraka, translated as 'Sabatang' (SBT), one of the most dangerous zones within the PS, which is typically avoided by ships and fishermen during the occurrence of high currents and waves. By contrast, this strait is one of fishermen's favourite sites because it has abundant fish resources. Despite this economic potential, this area is still slow because of a lack of energy supply in this underdeveloped region. For example, cold storage could not be maximised to support local fishery activities because of the lack of electricity supply.

\section{Materials and Methods}

\subsection{Data Acquisition}

The field survey in the PS was carried out to obtain the data to develop a numerical model and an energy resource assessment analysis. It included a high-precision singlebeam echo-sounder survey, with tidal observation at three locations, namely Gilalang, Tomara and SKI, and two static Acoustic Doppler Current Profiler (ADCP) measurements were performed for 1 month on April 2017 in two locations at the study area, Fig. 2. The current observations were located in the narrow part of the PS. ADCP measurements provide important characteristics of tidal currents such as speed, direction, vertical stratification and through-flow (Susanto et al., 2013). This measurement method has been implemented for longterm measurement at several places, for example, in the Black Sea (Zatsepin et al., 2012; Piotukh et al., 2016).

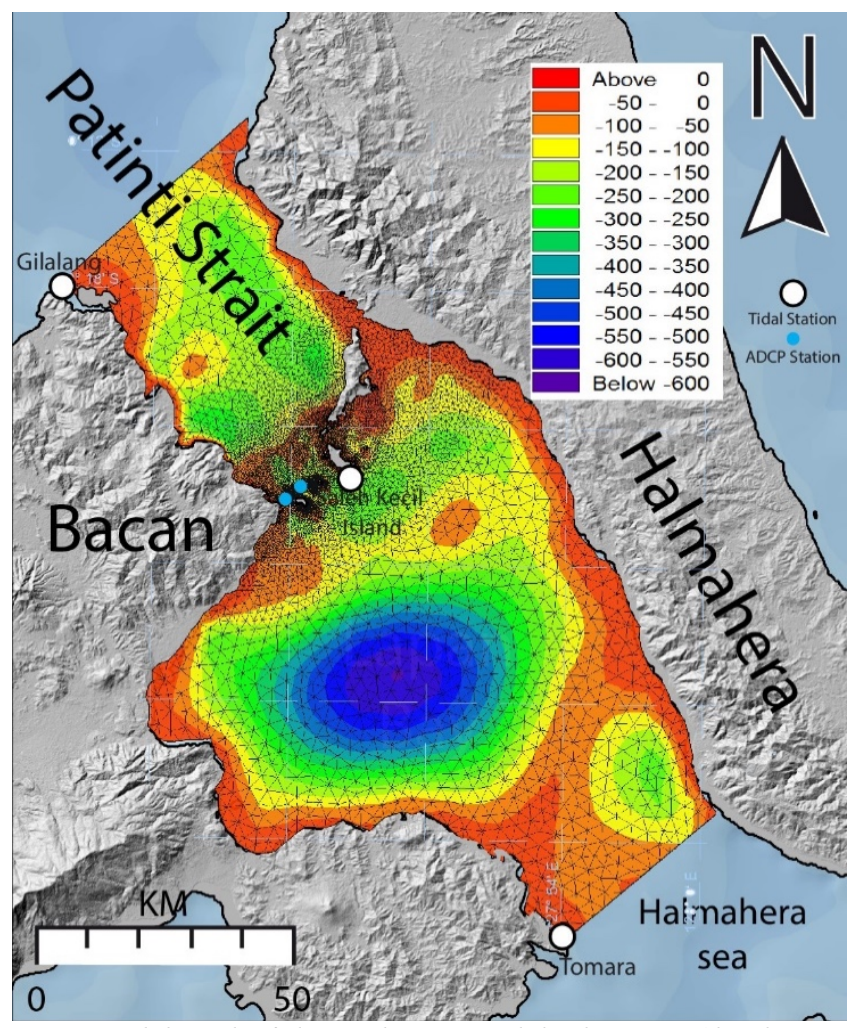

Fig. 2 Model mesh of the study area with bathymetry (depth is in Chart Datum; map projection is UTM 52S) 
The bathymetry data from the survey campaign are utilised as a primary input for the model mesh, whereas the water level and current measurements are for model calibration and validation purposes.

\subsection{Two-dimensional Hydrodynamic Model}

Hydrodynamic conditions are essential for the study of marine renewable energy (Woolf et al. 2014). The utilisation of hydrodynamic numerical modelling is mainly for the assessment of an energy resource and its environmental impact. The hydrodynamic model provides spatial information on a time period as an input for the resource assessment analysis in more efficient time and cost compared to other methods, such as direct measurement. This approach has been successfully implemented in several locations, such as Rathlin Sound, Northern Ireland (Ortiz et al., 2017), the northern part of Scotland and the Irish sea (Neill et al., 2017), the Gulf of Mexico and the east coast of Florida, United States (Dhanak et al., 2016), the Bay of Fundy and the Gulf of Maine, Canada (Hasegawa et al., 2011), Zhoushan (Yu et $a l ., 2017)$, the Eastern Region of Pingtan Island (He et al., 2017), and the Qiongzhou Strait (Wu et al., 2016) in China. The hydrodynamic conditions for the energy resource assessment in this study are based on the local scale numerical model simulation using MIKE 21 software package (flow model FM module). The model is a twodimensional state of the art with a flexible mesh based on the Navier-Stokes equation (DHI, 2012). The flexible mesh is able to resemble a complex coastal geometry and offers smooth domain downscaling, from a coarse mesh at the boundary to a finer resolution at the area of interest.

The software is governed by the integrated horizontal momentum equation and the continuity equation. The two-dimensional shallow water equation is shown by Eq (1)-(3):

$$
\frac{\partial h}{\partial t}+\frac{\partial h \bar{u}}{\partial x}+\frac{\partial h \bar{v}}{\partial y}=h S
$$

where each of the horizontal components of the formula are shown as:

$$
\begin{gathered}
\frac{\partial h \bar{u}}{\partial t}+\frac{\partial h \bar{u}^{2}}{\partial x}+\frac{\partial h \overline{v u}}{\partial y}=f \bar{v} h-g h \frac{\partial \eta}{\partial x}-\frac{h}{\rho_{0}} \frac{\partial p_{a}}{\partial x}-\frac{g h^{2}}{2 \rho_{0}} \frac{\partial \rho}{\partial x}+\frac{\tau_{s x}}{\rho_{0}}-\frac{\tau_{b x}}{\rho_{0}}- \\
\frac{1}{\rho_{0}}\left(\frac{\partial s_{x x}}{\partial x}+\frac{\partial s_{x y}}{\partial y}\right)+\frac{\partial}{\partial x}\left(h T_{x x}\right)+\frac{\partial}{\partial y}\left(h T_{x y}\right)+h u_{s} S
\end{gathered}
$$

and

$$
\begin{gathered}
\frac{\partial h \bar{v}}{\partial t}+\frac{\partial h \bar{v}^{2}}{\partial y}+\frac{\partial h \overline{u v}}{\partial x}=-f \bar{u} h-g h \frac{\partial \eta}{\partial y}-\frac{h}{\rho_{0}} \frac{\partial p_{a}}{\partial y}-\frac{g h^{2}}{2 \rho_{0}} \frac{\partial \rho}{\partial y}+\frac{\tau_{s y}}{\rho_{0}}-\frac{\tau_{b y}}{\rho_{0}} \\
-\frac{1}{\rho_{0}}\left(\frac{\partial s_{y x}}{\partial x}+\frac{\partial s_{y y}}{\partial y}\right)+\frac{\partial}{\partial x}\left(h T_{x y}\right)+\frac{\partial}{\partial y}\left(h T_{y y}\right)+h v_{s} S
\end{gathered}
$$

The depth-averaged velocities are defined by Eq (4)

$h \bar{u}=\int_{-d}^{n} u d z \& h \bar{v}=\int_{-d}^{n} v d z$

The numerical model domain extends along the entire PS between BI and Halmahera Island (Fig. 2). In most of the model domain, the bathymetry input for the model is retrieved from the GEBCO 2014 database with a resolution of 30 arc-seconds (Weatherall et al., 2015).

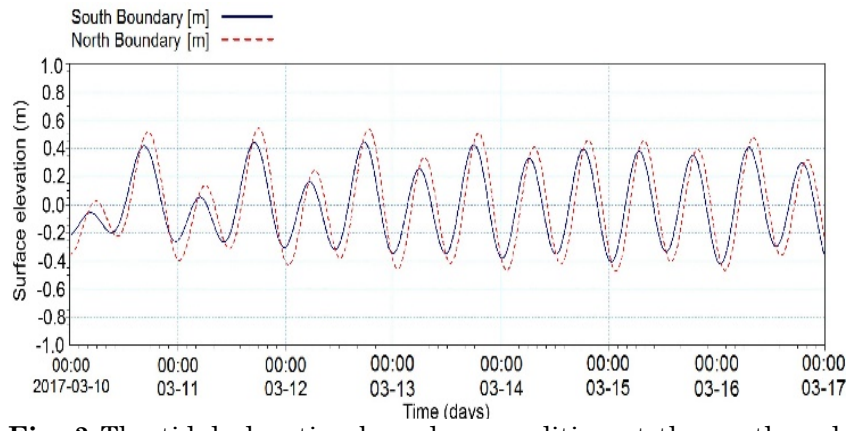

Fig. 3 The tidal elevation boundary condition at the north and south boundary

Around the proposed turbine location, close to SKI, the bathymetric data are supplemented by the detailed data from the field survey campaign described in the previous section. Both bathymetry datasets are combined and georeferred to the benchmark spot (chart datum). The grid resolution ranges from $1 \mathrm{~km}$ for the outer part of the model domain to $50 \mathrm{~m}$ on the narrow part of the strait where the proposed turbine is located.

The tidal information at boundaries is calculated from DHI's Global Tide Model (GTM). The GTM is based on TOPEX/POSEIDON altimetry data with a resolution of $0.125^{\circ}$ constructed from major diurnal (K1, O1, P1 and Q1) and semi-diurnal constituents (M2, S2, N2 and K2). Figure 3 illustrates the tidal variation at boundary conditions that indicate the tidal amplitude and phase differences between the two boundaries as the driving force of the hydrodynamic process. To ensure that the boundary information is accurate, the water level data derived from the TOPEX altimetry dataset have also been quantitatively validated to the ADCP measurements in the Japan Sea and it is confirmed as reliable (Ebuchi \& Hanawa 1995). In this study, the tidal level for the boundaries of the strait has been validated with the field measurements from the survey campaign.

\subsection{Resource Estimation Theory}

The fundamental criteria to determine tidal energy deployments' successful implementation are power density, scalability, durability, maintainability, economic feasibility and environmental impact (Roberts et al., 2016). To align with the principle of tidal energy deployments, a multi-criteria assessment methodology is critical in estimating the power potential harvested from the turbine.

Several reference studies have reviewed the best approach to optimising energy to be harvested. Examples are the fundamental formula behind the tidal turbine by Bryden et al., (2007), characteristics of the velocity profile and the seabed friction for reduction of the tidal velocity by Lewis et al., (2017), power generation as a function of horizontal axis of the turbine using the modelling approach by Mungar (2014) and tidal farm arrays for optimising the resource assessment by Lewis et al., (2015).

A resource energy assessment is also carried out to determine a suitable location for the turbine, selected through a multi-criteria analysis that accounts for the physical and environmental constraint. The criteria for the resource assessment are as follows:

- Hydrodynamic conditions: The assessment is based on the current speed condition from the hydrodynamic model simulation. Furthermore, 
average kinetic power densities are calculated using the following formula (Bryden et al., 2007):

$$
P=\frac{1}{2} \cdot \rho \cdot U^{3}
$$

$\mathrm{P}$ is tidal stream power per unit area of flow, $\rho$ is the density of seawater, and $\mathrm{U}$ is the current speed. The value used as the current speed is the undisturbed speed, where a tidal turbine is not involved in speed reduction due to energy extraction.

- Depth: The assessment follows two conditions; high capacity from 40 to $100 \mathrm{~m}$ and low capacity from 10 to $40 \mathrm{~m}$.

- $\quad$ Cut-in speed: the assessment is performed for cut-in speeds of $0.2 \mathrm{~m} / \mathrm{s}$ and $0.4 \mathrm{~m} / \mathrm{s}$.

\section{Result and Discussion}

\subsection{Model Validation}

The numerical model is validated with the survey measurements at two stations in the study area, the surface elevation data at SKI station (longitude: $127.7356^{\circ}$, latitude: $-0.4295^{\circ}$ ) and current at SBT Station (longitude: $127.7036^{\circ}$, latitude: $-0.4498^{\circ}$ ).

Based on the tidal and current residual analysis, the sites' hydrodynamic condition is predominantly tidal force, and the non-tidal components such as wind and surge are not significant. Therefore, model validation over the measurement period on March 2017 is valid for representing the annual condition.

Validation performance of the model for tide-driven current is illustrated in Fig. 4 and Fig. 5. The tidal current component from the measurement data is used for comparison at the validation process (Isobe et al., 2007). The comparison between the model and the measurements data (Figs. 4 and 5) indicates that the water level and current from the simulation are a reasonably close match and indicates a satisfactory agreement between the model and the measurements.

A validation requirement for hydrodynamic conditions for coastal application (Evans, 1993) is the root mean square error (RMSE) of the water level within $10 \%$ of spring tidal range or $15 \%$ of the neap tidal range $10 \%-20 \%$ of the measured current speed. The RMSE formula is as follows:

$$
R M S E=\sqrt{\sum_{i=1}^{n} \frac{\left(\text { Predicted }_{i}-\text { Actual }_{i}\right)^{2}}{n}}
$$

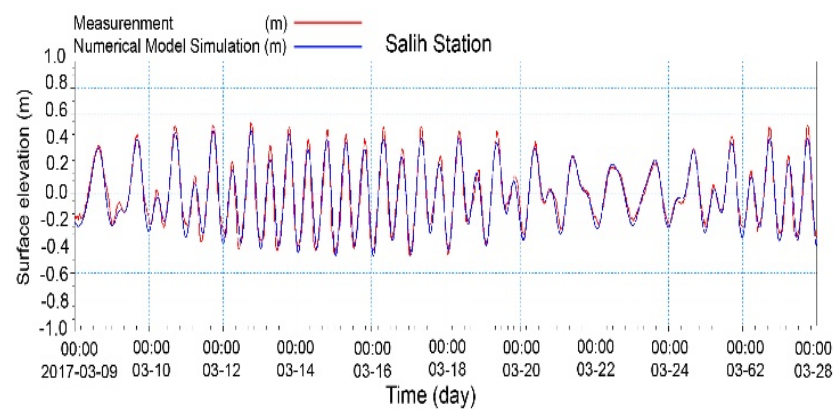

Fig. 4 Water level comparison between model simulation results and measurement at the SKI station (RMS error: $6.56 \mathrm{~cm}$ within an acceptable criteria range of $9.58 \mathrm{~cm}$ ).

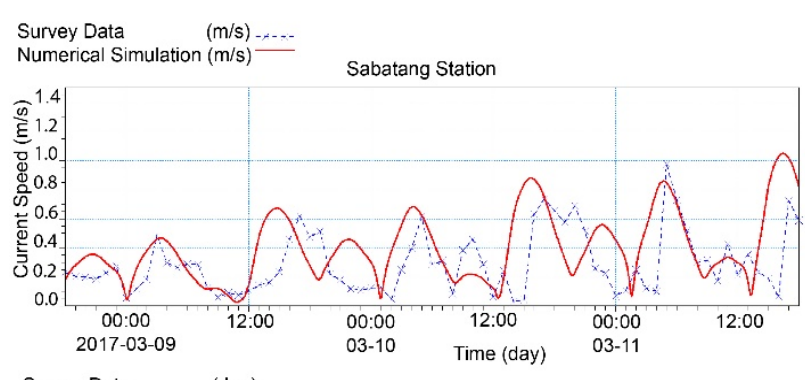

Survey Data (deg)
Numerical Simulation (deg)

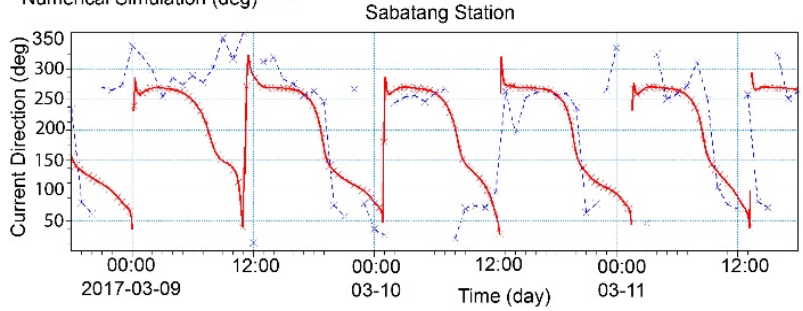

Fig. 5 Current velocity (RMS error: $0.18 \mathrm{~cm} / \mathrm{s}$ within an acceptable criteria range of $0.2 \mathrm{~m} / \mathrm{s}$ ) and direction comparison between model simulation results and measurements at the SBT Station

The validation indicates that the model result is quantitatively within the criteria range.

\subsection{Resource Assessment}

Resource assessment is an important aspect of marine turbine deployment. It provides a scientific basis for the technology product selection suitable to the site-specific hydrodynamic conditions (water level, current and bathymetry). Based on the model simulation, the potential energy resources could be assessed by perceiving the energy distribution of the tidal current form. Figure 6 illustrates current speeds in PS location. The highest current speed is predominantly between SKI and BI. The statistic calculation indicates that the highest mean current speed at PS is up to $0.6 \mathrm{~m} / \mathrm{s}$ (red colour) and reaches a maximum current speed reaches of $1.7 \mathrm{~m} / \mathrm{s}$. The mean current speed presents the highest mean resource around SBT, which is situated between BI and KI. The area between KI and PI also has a high mean current, although it is dispersed to a larger extent than that of SBT.

Figure 6 presents the pattern of the maximum current speed. The pattern of the highest current is still similar to that of the mean current speed, though a few peak spots appear in the southern part of KI up to $2.5 \mathrm{~m} / \mathrm{s}$. Based on these results, it can be determined that SBT has the most promising area to be developed. The maximum current speed is also situated not too far from the coastline. As the potential area is the closest to the coastline, SBT is one of the best places to be developed for marine tidal turbine in this region because with reduced distance from the coast, cost and risks of installation decrease This condition can be used to consider the distance of turbine structures to the onshore.

In summary, the model simulation result indicates that the western part of SKI is a suitable location for the turbine deployment, where the mean current speed is around $0.5-0.6 \mathrm{~m} / \mathrm{s}$ (Fig. 6A), and the maximum is more than $1.5 \mathrm{~m} / \mathrm{s}$ (Fig. 6B). Because SKI is an inhabited island that is still developing its tourism and fishing industry, the spot area would be valuable to consider. 


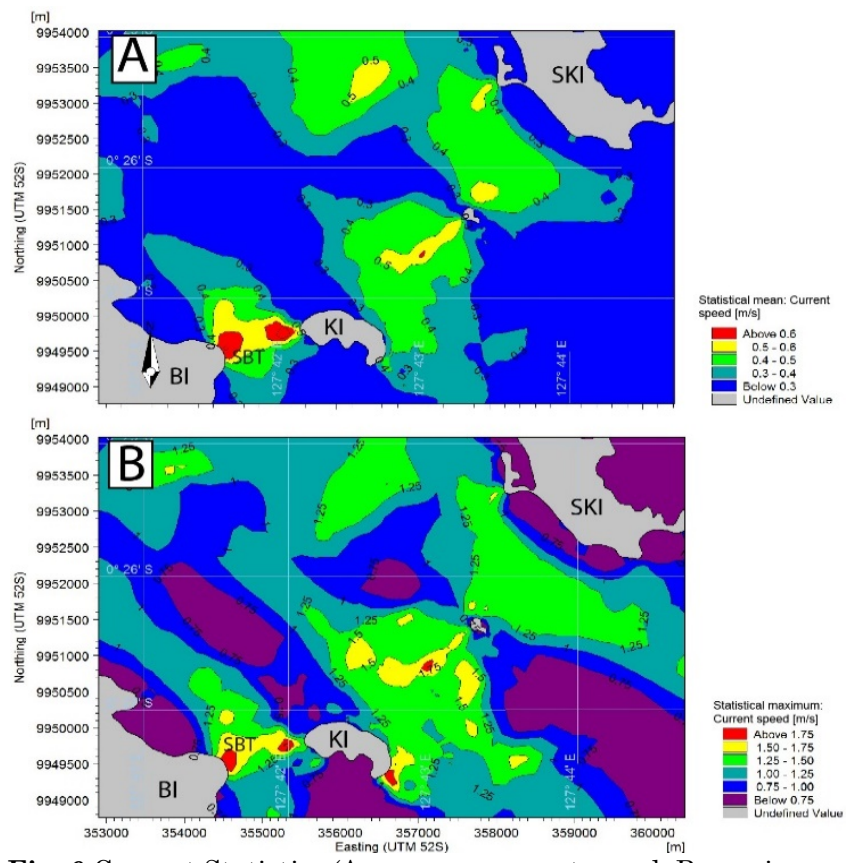

Fig. 6 Current Statistics (A: average current speed; B: maximum current speed)

Based on the current speed in Fig. 6A and Fig. 6B, the kinetic power density could be estimated. Resource estimation using the formula described by Bryden et al. (2007) yields the resource pattern illustrated in Fig. 7. In this figure, six observation points, P1 to P6, are determined by considering the closest to the coastline and the particularly water depth to illustrate the capacity of average kinetic power. Fig. 7A presents an average kinetic power density of the area between $\mathrm{BI}$ and $\mathrm{KI}$, where the observation points were selected. This figure also illustrates a potential area to be developed (orange to red colours) within more than $0.12 \mathrm{~kW} / \mathrm{m}^{2}$. Four observation stations, $\mathrm{P} 1, \mathrm{P} 2, \mathrm{P} 3$ and $\mathrm{P} 4$, are selected to illustrate the potential of marine current turbines related to their cutin speed (Table 1). The area with an average kinetic power density over $0.1 \mathrm{~kW} / \mathrm{m}^{2}$ covers approximately $234,810.00$ $\mathrm{m}^{2}\left(0.234 \mathrm{~km}^{2}\right)$. This area is potentially suitable for the development of marine current energy to provide electricity to BI, where Labuha, the capital city of South Halmahera Regency, currently has a significant demand for energy.

Furthermore, Figure 7B presents the kinetic power density in the southern part of the PS, where the highest average kinetic power density is centred in the western part of SKI, albeit the amplitude is smaller than that in SBT. The highest kinetic power density is from 0.06 to 0.14 $\mathrm{kW} / \mathrm{m}^{2}$, and the total area has more than $0.1 \mathrm{~kW} / \mathrm{m}^{2}$ over approximately $198,750.00 \quad \mathrm{~m}^{2} \quad\left(0.198 \quad \mathrm{~km}^{2}\right)$. Two observation points, $\mathrm{P} 5$ and $\mathrm{P} 6$, are also selected to illustrate marine current turbines' potential related to their cut-in speed, presented in Table 1.

Several marine turbine technologies that have been tested (e.g., De Groot, 2012); hence, European technologies would be considered to estimate potential energy yield (De Groot, 2012; Osalusi et al., 2009). The devices recently reviewed by Rourke et al. (2010) classify two types of technology: tidal barrage and tidal current turbines. Generally, for a $1 \mathrm{MW}$ capacity marine turbine, the cut-in speed is from $0.40 \mathrm{~m} / \mathrm{s}$ to $1.00 \mathrm{~m} / \mathrm{s}$, whereas for a smallercapacity turbine, around $300 \mathrm{~kW}$, the cut-in speed is in the range of $0.20-0.40 \mathrm{~m} / \mathrm{s}$.
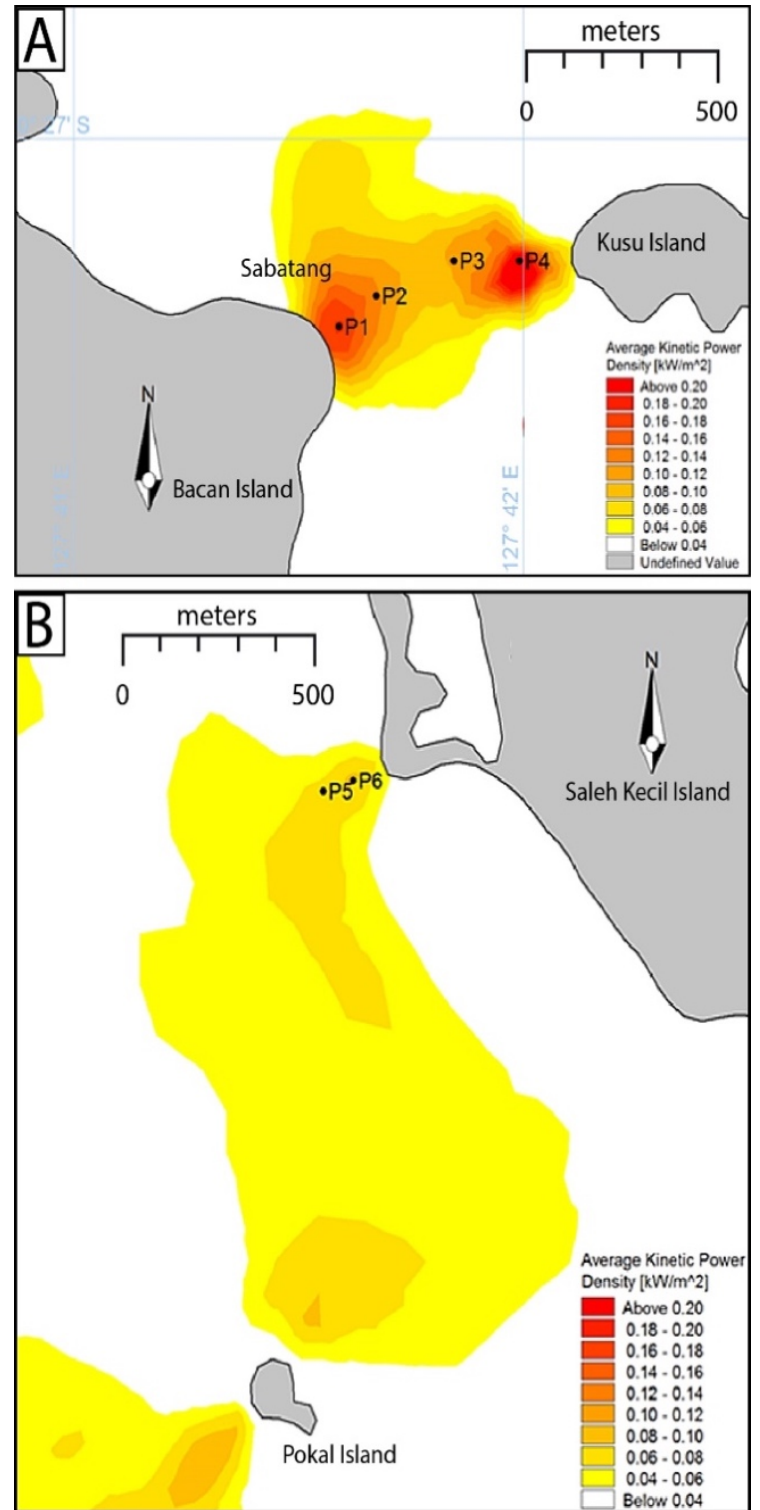

Fig. 7 Modelled spatial variation of average kinetic power density without depth limitation

Both capacities have different dimensions and technologies; consequently, each capacity has different water depth to be deployed. The high capacity requires deeper water depth than that of the low capacity. The low capacity is commonly installed in $10 \mathrm{~m}$ to $40 \mathrm{~m}$ of water depth, whereas the high capacity is installed between 40 and $100 \mathrm{~m}$ of water depth.

Figure 8 presents the location of high capacity of the average kinetic power, where the seabed contour overlays it from 40 to $100 \mathrm{~m}$. As it can be seen in Fig. 8A, the area of average kinetic power density in SBT with more than $0.10 \mathrm{~kW} / \mathrm{m}^{2}$ is around $97,970 \mathrm{~m}^{2}$, whereas in Fig. $8 \mathrm{~B}$, the area around SKI and PI reached 74,570 $\mathrm{m}^{2}$ and 100,020 $\mathrm{m}^{2}$, respectively.

Figure 9A illustrates the spatial variation of average kinetic power for the low-capacity condition in the SBT area. The area around BI with average kinetic power density of more than $0.10 \mathrm{~kW} / \mathrm{m}^{2}$ is $54,840 \mathrm{~m}^{2}$, whereas in the KI part, it is $82,000 \mathrm{~m}^{2}$. Close to PI and SKI areas, Fig. 9B Illustrates the kinetic power density area spread to $10,320 \mathrm{~kW} / \mathrm{m}^{2}$ and $13,840 \mathrm{~kW} / \mathrm{m}^{2}$, respectively. 

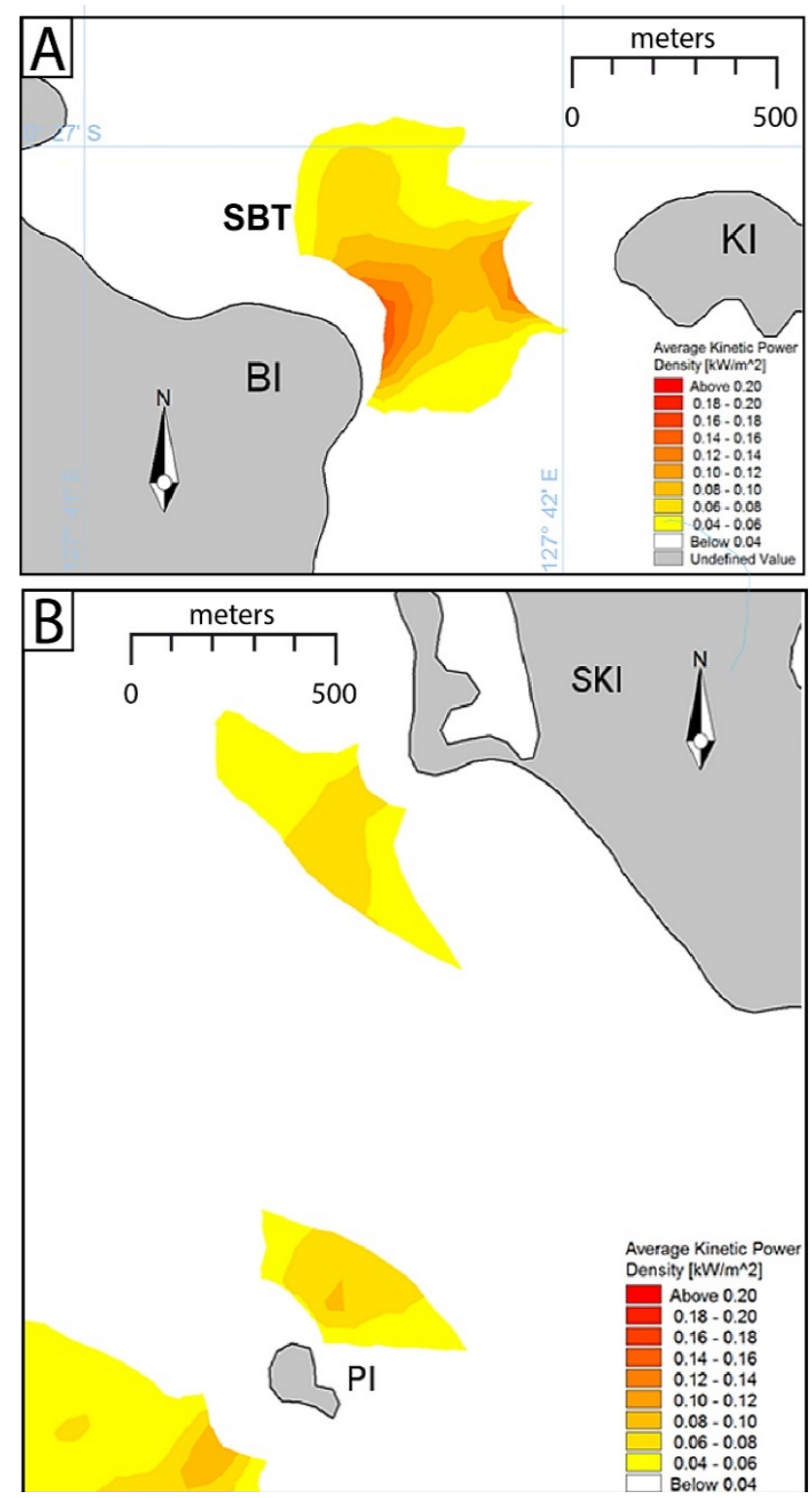

Fig. 8 Spatial variation for average kinetic power for the high capacity condition (depth between 40 and $100 \mathrm{~m}$ )

Since the low capacity of the average kinetic power is much more promising because it has higher percentage of operational hours (Table 1), the design of small turbines is placed in P1, P4, P6 and the area near PI, Fig. 9B. These locations are considered by the water depth and the average kinetic potential that is realistic to adopt for small turbines (Fraenkel, 2006).

$\mathrm{P} 1$ is designed for four turbines to be arrays within 200 $\mathrm{W} / \mathrm{m}^{2}$ areas of less $40 \mathrm{~m}$ water depth. Furthermore, the turbine interval is adjusted within a $160 \mathrm{~m}$ length toward the offshore (Fig. 9A). P4 is near KI, which has a potential of $200 \mathrm{~W} / \mathrm{m}^{2}$ over more than $20,000 \mathrm{~m}^{2}$ and at least seven small turbines can be placed within the interval of $70 \mathrm{~m}$ each and at $200 \mathrm{~m}$ toward to the offshore. P6 close to SKI has a smaller potential average kinematic power density than that in the area near PI, which is approximately 80 $\mathrm{W} / \mathrm{m}^{2}$, so one turbine is designed to be placed within less than $30 \mathrm{~m}$ water depth and $95 \mathrm{~m}$ from the coastline. Furthermore, the potential area near PI is planned to apply at least four small turbines within the interval $55 \mathrm{~m}$ and $100 \mathrm{~W} / \mathrm{m}^{2}$ kinematic power density.
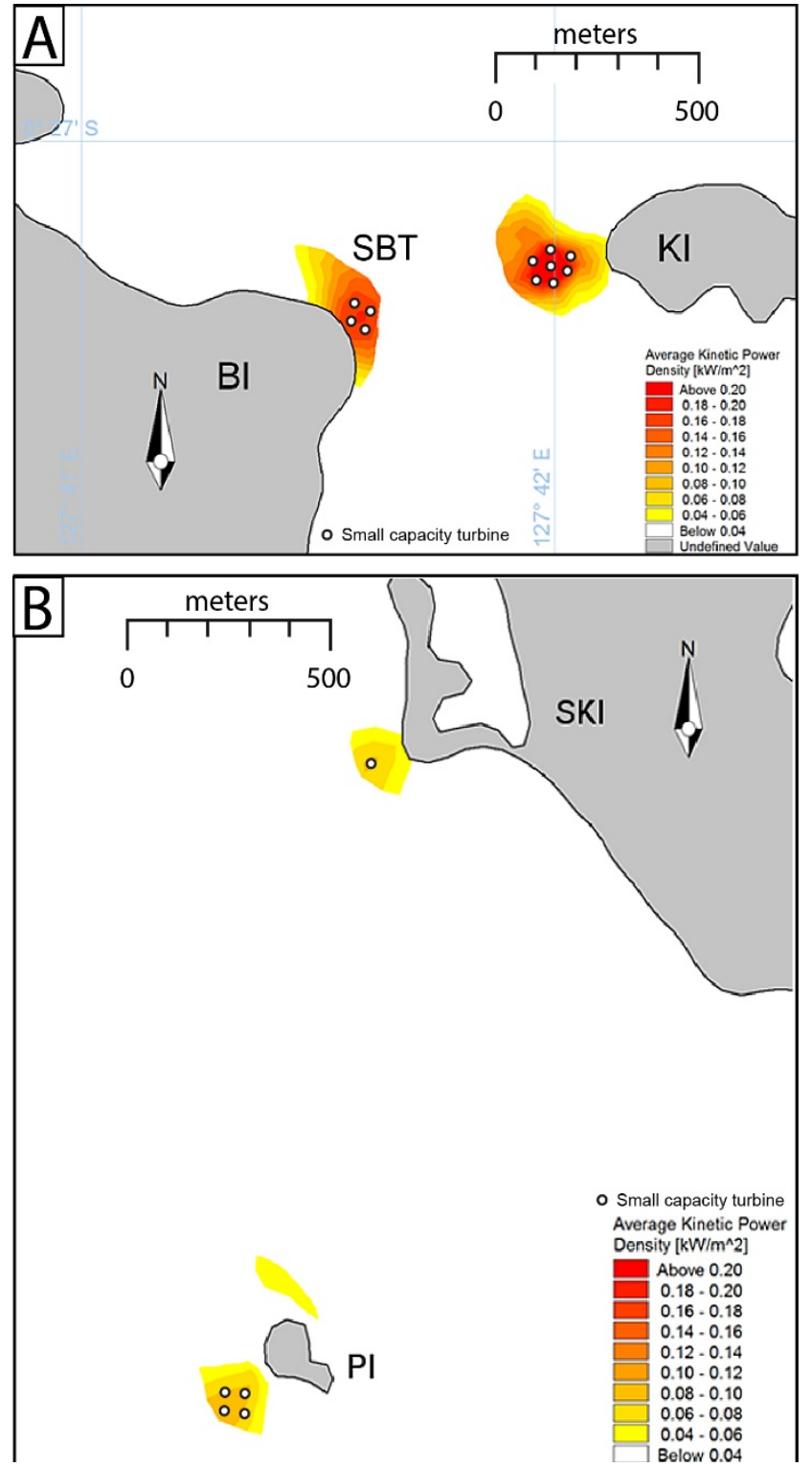

Fig. 9 Spatial variation of average kinetic power for the lowcapacity condition (depth between 10 and $40 \mathrm{~m}$ )

Table 1 presents the availability percentage time duration as an energy resource based on the cut-in speed. Six stations are selected to represent the potential area, as illustrated in Fig. 7. The most operational points are P1 and $\mathrm{P} 4$, placed in SBT. In consideration the narrow width of this area, which is approximately $1 \mathrm{~km}$, and the lack of renewable energy in $\mathrm{BI}$, the area can be considered to be of high potential interest, and it is feasible to develop a marine energy project. Besides, $\mathrm{P} 6$ is a great location to be explored too as SKI is inhabited and is developing the tourism and fishery industry.

Table 1

Percentage of running time based on cut-in speed

\begin{tabular}{ccc}
\hline \multirow{2}{*}{ Station } & \multicolumn{2}{c}{ Percentage of operational hours } \\
\cline { 2 - 3 } & $\begin{array}{c}\text { Cut-in Speed: } \\
0.2 \mathrm{~m} / \mathrm{s}\end{array}$ & Cut-in Speed: $0.4 \mathrm{~m} / \mathrm{s}$ \\
\hline P1 & 85.7 & 69.0 \\
P2 & 82.9 & 64.7 \\
P3 & 83.0 & 63.6 \\
P4 & 91.3 & 74.7 \\
P5 & 77.7 & 54.4 \\
P6 & 83.8 & 58.3 \\
\hline
\end{tabular}


In consideration of the average percentage of a small turbine, cut-in speed reaches $84 \%$, whereas the larger turbine reaches $64 \%$; hence, the practice of the small turbine is more promising. Areas of $\mathrm{P} 1$ and $\mathrm{P} 4$ that is closest to the $\mathrm{BI}$ and $\mathrm{KI}$ are of high priority and can be applied because the off-grid system will be much more economically and easily constructed than those in other locations.

\subsection{Potential Impact}

The energy resources harvested on the study sites potentially provide a platform of the development of the surrounding area. They will improve the local livelihood, such as basic needs, and offer opportunities for the local economic growth. However, it is also important to assess any environmental impact of the tidal turbine activities to the potential receptors in the area of interest. First, researchers have demonstrated that tidal turbines' energy extraction results in flow change from the turbine to a regional scale (Adcock et al., 2015). In numerical modelling, the turbines' impact can be represented using the bottom friction method as demonstrated by Blunden and Bahaj (2015) or using the momentum sink approach performed by O'Brien et al. (2015). The bottom friction method is more practical. However, for the threedimensional model, the latter option provides a more realistic simulation (Perez-Ortiz et al., 2017).

The scale of water level and velocity changes depends on the installed turbine, where a larger array affects a more significant consequence. However, Draper et al. (2014) found that multiple arrays may increase one another's efficiency. Bed shear stress is also affected following the flow changes (Waldman et al., 2017). Furthermore, Neill et al. (2009) demonstrated the possible impact of erosion and deposition around the turbines on the sediment dynamics at the site depending on the turbine scale.

Inger et al. (2009), Hastie et al. (2014), and Haslett et al. (2016) indicate that there is an interaction between marine biodiversity and the tidal turbine. Besides the environmental concern, it is also important to investigate the social impact. As a relatively new technology, public acceptance (Devine-Wright, 2011; Lim \& Lam, 2014) and stakeholder engagement (Johnson et al., 2013; Zydlewski et al., 2014) are also required to successfully implement this technology.

\section{Conclusion}

This study used numerical modelling with inputs from in situ survey campaigns. The output of the numerical model simulation was then utilised for an energy resource assessment. Besides the magnitude of current speed derived from the model result, the energy estimation considers important parameters such as the depth and cut-in speed. The assessment results indicate that the tidal turbine is a potential source of energy in PS. The study also indicates that SBT holds the highest potential for energy resource in PS but is also famously known for its harsh condition; hence, the safety factor becomes an important parameter to consider. To move forward, a detailed study of the design aspects is especially required for tidal turbine technology prior the implementation of the design. Besides the battery saving, it is also an important entity for maximising the energy because the operation hours still have a limitation.

It is important for further expansion to investigate the Indonesian Through-flow (ITF) components because the study area is within the ITF zone (Gordon, 2005). Meyer et al. (2014) demonstrated through-flow as a source of energy, suggesting that the ITF might be important to consider. Also, in future study, it is recommended to incorporate the speed reduction due to energy extraction by tidal turbines, which will yield a more realistic value for the generated power.

\section{Author Contributions}

Author Contributions: Conceptualisation, F.N. and E.H.S.; methodology, F.N. and D.M.; software, F.N, A.E. and M.M; model simulation and validation, A.E. and F.N.; formal analysis, F.N. and E.H.S.; investigation, E.H.S. and F.N.; resources, E.H.S, A.E and F.N.; data curation, D.M., E.H.S and M.M.; writing-original draft preparation, F.N. and E.H.S; writing - review and editing, F.N., E.H.S., D.M., AE and M.M.; visualisation, A.E., E.H.S., M.B.P and M.M; supervision, D.M.; project administration, E.H.S.; funding acquisition, F.N. and E.H.S. All authors have read and approved the published version of the manuscript.

\section{Acknowledgements}

This study was fully supported by the Ministry of Energy and Mineral Resources, the Republic of Indonesia. The field activities were granted by contract number 1910.967.054.E.524111. The authors also thank all the team and local government of North Maluku Province and the blind reviewer who provided useful information for this study.

\section{References}

Adcock, T.A.A., Draper, S., \& Nishino, T. (2015). Tidal Power Generation - A Review of Hydrodynamic Modelling. in: Proceeding of the Institution of Mechanical Engineers. Part A: Journal of Power and Energy, 229, 755-711. doi:10.1177/0957650915570349

Ajiwibowo, H., Pratama, M.B., \& Wurjanto, A. (2017). Assessment of Tidal Current Power Potency in Kelabat Bay, Indonesia. International Journal of Engineering and Technology, 9(4), 3100-3110. doi:10.21817/ijet/2017/v9i4/170904089

Blunden, L.S., \& Bahaj, A.S. (2007). Effects of tidal energy extraction at Portland Bill, southern UK predicted from a numerical model. Proceedings of the 7th European Wave and Tidal Energy Conference.

Blunden, L.S., Bahaj, A.S., \& Aziz, N.S. (2013). Tidal current power for Indonesia? An initial resource estimation for the Alas Strait. Renewable Energy, 49, 137-142. doi:10.1016/j.renene.2012.01.046. Accessed on 5 November 2019

BP (2019) BP Statistical Review of World Energy, 68th ed. British Petroleum.

Bryden, I.G., Couch, S.J., Owen, A, \& Melville, G. (2007). Tidal current resource assessment. in: Proceeding of the Institution of Mechanical Engineers Part A: Journal of Power and Energy, 221(2), 125-135. doi:10.1243/09576509JPE238. Accessed on 30 January 2019 
De Groot, N (2012) Tidal power in the Klabat bay, Indonesia. MSc Thesis Report, Delft University of Technology, Delft.

Devine-Wright, P. (2011). Place attachment and public acceptance of renewable energy: A tidal energy case study. Journal Environmental Psychology, 31, 336-343. doi:10.1016/j.jenvp.2011.07.001. Accessed on 23 September 2019

Dhanak, M.R., Duerr, A.E.S., \& Van Zwieten, J.H. (2016). Marine hydrokinetic energy resource assessment. Springer Handbook of Ocean Engineering, 1099-1116. doi:10.1007/978-3-319-16649-0 44. Accessed on 11 April 2019

DHI. (2012). MIKE 21 \& MIKE 3 FLOW MODEL FM: Hydrodynamic and Transport Module Scientific Documentation. DHI, Horsholm.

Draper, S., Adcock, T.A.A., Borthwick, A.G.L., \& Houlsby, G.T. (2014). Estimate of the tidal stream power resource of the Pentland Firth. Renewable Energy, 63, 650-657. doi:10.1016/i.renene.2013.10.015

Ebuchi N., \& Hanawa K. (1995). Comparison of Surface Current Variations Observed by TOPEX Altimeter with TOLEXADCP Data. Journal of Oceanography, 51, 351-362. doi:10.1007/BF02285171. Accessed on 15 October 2019

Evans, G.P. (1993). A Framework for Marine and Estuarine Model Specification in the UK. Research Report FR0374, Foundation for Water Research, Buckinghamshire.

Fraenkel, P.L. (2006). Marine current turbines: pioneering the development of marine kinetic energy converters. Journal Power and Energy, 221, 159-169. doi:10.1243/09576509JPE307 Accessed on 2 June 2019

Firdaus, A.M., Houlsby, G.T., \& Adcock, T.A.A. (2020). Tidal energy resource in Larantuka Strait, Indonesia. Energy, 173(2), 81-92. doi:10.1680/jener.19.00042

Firdaus, A.M., Houlsby, G.T., \& Adcock, T.A.A. (2019). Resource estimates in Lombok Straits, Indonesia. Proceedings of the 13th European Wave and Tidal Energy Conference.

Gordon, A.L. (2005). Oceanography of the Indonesian seas and their through flow. Oceanography, 18, 14-27. doi:10.5670/oceanog.2005.01

Haslett, J.R., Garcia-Llorente, M., Harrison, P.A., Li, S., \& Berry, PM. (2016). Offshore renewable energy and nature conservation: the case of marine tidal turbines in Northern Ireland. Biodiversity Conservation, 27, 1619-1638. doi:10.1007/s10531-016-1268-6. Accessed on 7 June 2019

Hasegawa, D., Sheng, J., Greenberg, D.A., \& Thompson, K.R. (2011). Far-field effects of tidal energy extraction in the Minas Passage on tidal circulation in the Bay of Fundy and Gulf of Maine using a nested-grid coastal circulation model. Ocean Dynamics, 61, 1845-1868. doi:10.1007/s10236-0110481-9. Accessed on 15 June 2019

Hastie, G., Gillespie, D., Gordon. J., Macaulay. J., McConnell, B., \& Sparling, C. (2014). Tracking Technologies for Quantifying Marine Mammal Interactions with Tidal Turbines: Pitfalls and Possibilities, In: Shield. M., Payne A. Marine Renewable Energy Technology and Environment Interactactions, 127-139. doi:10.1007/978-94-017-80025 10. Accessed on 13 November 2019

He, W., Xin, W., Bingzhen, W., Yang, B., \& Peitao, W. (2017). Evaluation of tidal stream energy and its impacts on surrounding dynamics in the Eastern Region of Pingtan Island, China. Chinese Journal of Oceanology and Limnology, 35, 1319-1328. doi:10.1007/s00343-017-0187-z. Accessed on 15 June 2019

Inger, R., Attrill, M.J., Bearhop, S., Broderick, A.C., James Grecian W., Hodgson D.J., Mills C., Sheehan E., Votier S.C., Witt., M.J, \& Godley., B.J. (2009). Marine renewable energy: Potential benefits to biodiversity? An urgent call for research. Journal of Applied Ecology, 46, 1145-1153. doi:10.1111/j.1365-2664.2009.01697.x. Accessed on 15 June 2019

Isobe, A., Kuramitsu, T., Nozaki, H., \& Chang, P.H. (2007). Reliability of ADCP data detided with a Numerical Model on the East China Sea Shelf. Journal of Oceanography, 63,
135-141. doi:10.1007/s10872-007-0011-z. Accessed on 15 June 2019

Johnson, T.R., Jansujwicz, J.S., \& Zydlewski, G. (2013). Tidal Power Development in Maine: Stakeholder Identification and Perceptions of Engagement. Estuaries and Coasts, 38, 266-278. doi:10.1007/s12237-013-9703-3. Accessed on 15 June 2019

Kementerian ESDM (2017) Peta Potensi Energi Arus Indonesia. Internal Report, Badan Litbang Energi dan Sumber Daya Mineral, Pusat Penelitian dan Pengembangan Geologi Kelautan, Bandung.

Lewis, M., Neill, S.P., Robins, P., Hashemi, M.R., \& Ward, S. (2017). Characteristics of the velocity profile at tidal-stream energy sites. Renewable Energy, 114, 258-272. doi:10.1016/j.renene.2017.03.096. Accessed on 15 June 2019

Lewis, M., Neill, S.P., Robins, P.E., \& Hashemi, M.R., 2015. (2015) Resource assessment for future generations of tidalstream energy arrays. Energy, 83, 403-415. doi:10.1016/j.energy.2015.02.038. Accessed on 15 June 2019

Lim, X.L., \& Lam, W.H. (2014). Public Acceptance of Marine Renewable Energy in Malaysia. Energy Policy, 65, 16-26. doi:10.1016/j.enpol.2013.09.053. Accessed on 15 June 2019

Meyer, I., Reinecke, J., \& Van Niekerk, J.L. (2014). Resource Assessment of the Agulhas Current for the Purpose of Marine Energy Extraction. In the 5th International Conference on Ocean Energy.

Ministry of Energy and Mineral Resources Republic of Indonesia (2018) Keputusan Menteri Energi dan Sumber Daya Mineral Republik Indonesia Nomor 1772 $K / 20 / M E M / 2018$. Kementerian Energi dan Sumber Daya Mineral, Republik Indonesia, Jakarta.

Mungar, S. (2014) Hydrodynamics of horizontal-axis tidal current turbines. MSc Thesis Report, Delft University of Technology, Delft.

Neill, S.P., Vögler, A., Goward-Brown, A.J., Baston, S., Lewis, M.J., Gillibrand, P.A., Waldman, S., \& Woolf, D.K. (2017). The wave and tidal resource of Scotland. Renewable Energy, 114, 3-17. doi:10.1016/j.renene.2017.03.027. Accessed on 15 June 2019

Neill, S.P., Litt, E.J., Couch, S.J., \& Davies, A.G. (2009). The Impact of Marine Renewable Energy Extraction on Sediment Dynamics. Marine Renewable Energy, 34, 28032812. doi:10.1016/j.renene.2009.06.015. Accessed on 15 June 2019

NOAA (2020) Climate at a Glance: Global Mapping. https://www.ncdc.noaa.gov/cag/. Accessed on 13 December 2020.

Novico, F., Astawa, I.N., Sinaga, A., \& Ali, A. (2015). Seafloor Morphology Influences on Current Condition in a Sunda Strait Bridge Project Using Numerical Model. Bulletin of The Marine Geology, 30, 55-66. https://doi.org/10.32693/bomg.30.2.2015.75. Accessed on 25 September 2018

O’Brien, N., O'Donncha, F., \& Ragnoli, E. (2015). A multiple layer modelling approach to investigate the effects of tidal turbine deployment. OCEANS 2015 - Genova: Discovering Sustainable Ocean Energy for a New World. doi:10.1109/OCEANS-Genova.2015.7271496

OES (2019) Annual report: An overview of ocean energy activities in 2019. Ocean Energy Systems.

Orhan, K., \& Mayerle, R. (2020). Potential hydrodynamic impacts and performances of commercial-scale turbine arrays in the strait of Larantuka, Indonesia. Journal of Marine Science and Engineering, 8(3), 223. doi:10.3390/jmse8030223

Orhan, K., Mayerle, R., \& Pandoe, W.W. (2015). Assesment of energy production potential from tidal stream currents in Indonesia. Energy Procedia, 76, 7-16. doi:10.1016/i.egvpro.2015.07.834 Accessed on 15 June 2019

Ortiz AP., Borthwick A.G.L., McNaughton J., \& Avdis A. (2017). Characterisation of the tidal resource in Rathlin Sound. Renewable Energy, 114, Part A, 229-243. doi:10.1016/i.renene.2017.04.026. Accessed on 5 June 2020

Osalusi, E., Side, J., \& Harris, R. (2009). Structure of turbulent flow in EMEC's tidal energy test site. International 
Communications in Heat Mass Transfer, 36, 422-431. doi:10.1016/j.icheatmasstransfer.2009.02.010. Accessed on 15 January 2019

Pérez-Ortiz, A., Borthwick, A.G.L., McNaughton, J., \& Avdis, A. (2017). Characterisation of the tidal resource in Rathlin Sound. Renewable Energy, 114, 229-243. doi:10.1016/i.renene.2017.04.026

Piotukh, V.B., Baranov, V.I., Kuklev, S.B., \& Podymov, O.I. (2016). Results of test experiment comparing measurement data of three adjacent ADCP bottom stations. Oceanology, 56, 601-613. doi:10.1134/S0001437016030164. Accessed on 15 November 2019

PLN (2018) 3.2 Sumber Energi Terbarukan: Rencana Usaha Penyediaan Tenaga Listrik PT. PLN (Persero) 2018-2027: III-5. Perusahaan Listrik Negara, Jakarta.

Pratama, M.B., Venugopal, V., Ajiwibowo, H., Ginting, J.W., \& Novico, F. (2020). Modelling Tidal Flow Hydrodynamic of Sunda Strait, Indonesia. Indonesian Journal of Marine Sciences, 25, 165-172. doi:10.14710/ik.ijms.25.4.165-172

Pushidros TNI AL. (2011). Peta Kedalaman Halmahera - Pantai Barat Makian hingga Teluk Gane dan Pulau - pulau Bacan Skala 1: 200.000.

Rahmawati, S. (2017). Study on characteristic of tidal current energy and ocean environmental pollution at Indonesia Archipelago. $\mathrm{PhD}$ thesis, Hiroshima University, Hiroshima.

Ritchie, H., \& Roser, M. (2017). $\mathrm{CO}_{2}$ and Greenhouse Gas Emissions. https://ourworldindata.org/co2-and-othergreenhouse-gas-emissions. Accessed on 13 December 2020.

Roberts, A., Thomas, B., Sewell, P., Khan, Z., Balmain, S., \& Gillman, J. (2016). Current tidal power technologies and their suitability for applications in coastal and marine areas. Journal of Ocean Engineering and Marine Energy, 2, 227-245. doi:10.1007/s40722-016-0044-8. Accessed on 15 June 2019

Rourke, F.O., Boyle, F., \& Reynolds, A. (2010). Tidal energy update 2009, Applied Energy 87, 398-409. doi:10.1016/j.apenergy.2009.08.014. Accessed on 15 December 2019

Sudjono, E.H., Ilahude, D., Raharjo, P., Hermansyah, G.M., Wahib, A., Lugra, I.W., Yuningsih, A., Ningsih, N.S., Suprijo, T., \& Ibrahim, A. (2014). Kajian teknis potensi sumber energi arus laut si Selat Molo, Boleng, Pantar, dan Riau. Internal Report, Kementerian Energi dan Sumber Daya Mineral, Badan Litbang Energi dan Sumber Daya Mineral, Pusat Penenlitian dan Pengembangan Geologi Kelautan, Bandung.
Susanto, R.D., Wei, Z., Adi, R.T., Fan, B., Li S., \& Fang, G. (2013). Observations of the Karimata Strait throughflow from December 2007 to November 2008. Acta Oceanologica Sinicia, 32, 1-6. doi:10.1007/s13131-013-0307-3. Accessed on 15 November 2019

Susilohadi., Sudjono, E.H., Yuinigsih, A., Yosi, M., Rachmat, B., Saputra, M.D., Ilahude, D., \& Prabowo, H. (2014). Ringkasan pemetaan dan pemodelan energi arus laut di selat-selat berpotensi Indonesia 2006 - 2013. Internal Report, Kementerian Energi dan Sumber Daya Mineral, Badan Litbang Energi dan Sumber Daya Mineral, Pusat Penenlitian dan Pengembangan Geologi Kelautan, Bandung.

Waldman, S., Bastón, S., Nemalidinne, R., Chatzirodou, A., Venugopal, V., \& Side, J. (2017). Implementation of tidal turbines in MIKE 3 and Delft3D models of Pentland Firth \& Orkney Waters. Ocean and Coastal Management, 147, 21-36. doi:10.1016/j.ocecoaman.2017.04.015

Weatherall, P., Marks, K.M., Jakobsson, M., Schmitt, T., Tani, S., Arndt, J.E., Rovere, M., Chayes, D., Ferrini, V., \& Wigley, R. (2015). A new digital bathymetric model of the world's oceans. Earth and Space Sciences, 2, 331-345. doi:10.1002/2015EA000107. Accessed on 15 June 2019

Woolf, D.K., Easton, M.C., Bowyer, P.A., \& Mcllvenny, J. (2014). The Physics and Hydrodynamic Setting of Marine Renewable Energy. Marine Renewable Energy Technology and Environmental Interactions, 5-20. doi:10.1007/978-94017-8002-5_2. Accessed on 15 June 2019

Wu, H., Yu, H., Ding, J., \& Yuan, D. (2016). Modelling assessment of tidal current energy in the Qiongzhou Strait, China. Acta Oceanologic Sinicia, 35, 21-29. doi:10.1007/s13131-0160792-2. Accessed on 15 June 2019

Yu, Z., Zhang, J., Zhai, Y., Zhang, T., \& Zheng, J. (2017). Numerical hydrodynamics study around the turbine array of tidal stream farm in Zhoushan, China. Journal of Ocean Univiversity of China, 16, 703-708. doi:10.1007/s11802017-3451-0. Accessed on 2 December 2019

Zatsepin, A.G., Piotouh, V.B., Korzh, A.O., Kukleva, O.N., \& Soloviev, D.M. (2012). Variability of currents in the coastal zone of the Black Sea from long-term measurements with a bottom mounted ADCP. Oceanology, 52, 579-592. doi:10.1134/S0001437012050177. Accessed on 15 April 2019

Zydlewski, G.B., Copping, A.E., \& Redden, A.M. (2015). Special Issue: Renewable Ocean Energy Development and the Environment. Estuaries and Coasts, 38, 156-158. doi:10.1007/s12237-014-9922-2. Accessed on 23 May 2019 